\title{
DIFUSI PENINGKATAN KAPASITAS KELEMBAGAAN PENGELOLAAN SUMBERDAYA PERIKANAN (Studi Kasus di Waduk Malahayu, Brebes Jawa Tengah)
}

\author{
Istiana dan Zahri Nasution \\ Balai Besar Penelitian Sosial Ekonomi Kelautan dan Perikanan \\ JI. KS. Tubun Petamburan VI Jakarta 10260 \\ Telp. (021) 53650162, Fax. (021)53650159 \\ e-mail: isti0112@yahoo.com \\ Diterima 18 Maret 2013- Disetujui 25 Mei 2013
}

\begin{abstract}
ABSTRAK
Penelitian ini bertujuan menggali informasi tentang difusi peningkatan kapasitas kelembagaan masyarakat berbasis pengelolaan sumberdaya perikanan. Peningkatan kapasitas tersebut merupakan inovasi dalam pengelolaan sumberdaya perikanan. Inovasi yang dimaksud pada penelitian ini adalah peningkatan kapasitas kelembagaan pengelolaan sumberdaya perikanan. Penelitian kualitatif ini dilakukan pada bulan Juli 2012 pada nelayan di Waduk Malahayu, Brebes Jawa Tengah dengan mengangkat kasus inovasi peningkatan kapasitas kelembagaan lokal. Lokasi dan sasaran penelitian ditentukan dengan sengaja, mengikuti lokasi penerapan program BalitbangKP. Hasil penelitian menunjukkan bahwa inovasi yang dikenalkan pada masyarakat nelayan merupakan inovasi baru dengan memanfaatkan kelembagaan lokal. Belum ada anggota masyarakat lainnya yang menggunakan inovasi yang dikenalkan. Respon masyarakat $(97,22 \%)$ terhadap inovasi karena sudah sesuai dengan kebutuhan masyarakat nelayan. Penetapan lokasi atau lokasi penerapan inovasi sejalan dengan kebijakan dan Program Pemerintah Daerah yaitu pemberdayaan ekonomi masyarakat. Inovator dalam difusi inovasi adalah tim Balitbang KP. Sebanyak 92,86\% responden menyatakan bahwa mereka merespon inovasi tersebut karena mudah dipraktekkan.
\end{abstract}

Kata kunci: difusi, inovasi, kelembagaan

\section{Abstract : Diffusi of Institutional Enhancement Capacities on Fisheries Resource Management (Case Studies in Reservoir Malahayu, Brebes, Central Java). By: Istiana and Zahri Nasution.}

The purpose of this research is to explore information about diffuse of institutions enhancement capacity which was based fisheries resource management. The institutions enhancement capacities are innovation in fisheries resource management. They are institutional enhancement capacities on fisheries resource management. This qualitative study was conducted in July 2012 to the fishermen community in Reservoir Malahayu, Brebes, Central Java. The cases explained was capacity enhancement of local institutional innovation. Determination of location and objectives research was selected purposively, which was based on the application location Research and and Development of Marine and Fisheries Agency programs. The results explained that the innovations introduced is a new innovation that utilizes local institutions. There are no other community members who use innovation introduced. Fisheries Community responses the innovation about $97.22 \%$ because it suits their needs. Determination of the location based on the fishermen appropriate with the Local Government policies and programs are economic empowerment. Innovators in the diffusion of innovation is a team of Research and and Development of Marine and Fisheries Agency. About 92.86\% respondent claimed that they respond to such innovations as easily practiced.

Keywords : diffusion, innovation, institutional

\section{PENDAHULUAN}

Pembangunan waduk pada umumnya dimaksudkan untuk peningkatan kesejahteraan masyarakat. Pemanfaatan waduk saat ini diarahkan untuk pembangkit listrik tenaga air (PLTA), irigasi, pengendali banjir, sumber air minum, usaha perikanan dan pariwisata. Pembangunan waduk Malahayu yang diharapkan dapat memberikan kesejahteraan bagi masyarakat sekitarnya. Salah satu kelompok masyarakat yang menggantungkan kelangsungan hidup pada keberadaan waduk Malahayu adalah nelayan dengan aktivitas penangkapannya. Berbeda dengan nelayan perairan umum lainnya, kegiatan usaha perikanan di waduk Malahayu berbasis ranching yaitu dengan cara menebarkan benih ikan dan dibiarkan selama beberapa bulan (umumnya empat bulan) dan selanjutnya dilakukan kegiatan penangkapan. Menurut Effendi (2004) menjelaskan bahwa ranching adalah pemeliharaan ikan dalam suatu kawasan perairan dan kawasan tersebut memiliki isolasi alamiah sehingga ikan yag ditebar (restocking) bisa di pastikan tidak berpindah tempat dan dapat ditangkap kembali (recapture).

Namun, kehidupan nelayan waduk Malahayu mengalami penurunan akibat penurunan pendapatan yang disebabkan adanya penurunan hasil tangkapan. Penurunan hasil tangkapan diduga akibat dayadukung perairan waduk yang menurun sehingga produktivitasnya tidak optimal lagi. Hal tersebut 
didukung hasil penelitian Wahyudi dan Santoso (2002) yang menjelaskan bahwa kondisi fisik waduk saat ini telah mengalami perubahan karena lajunya sedimentasi, sehingga mengakibatkan terjadinya penyempitan genangan perairan yang semula 925 ha saat ini tersisa 720 ha dengan volume air $37.074 \mathrm{~m}^{3}$.

Pada waduk Malahayu terdapat satu kelompok masyarakat yang melakukan pengelolaan perairan waduk yaitu kelompok nelayan Nila Jaya, kelompok ini terbentuk sejak tahun 1984. Dengan menurunnya produksi penangkapan, kehidupan nelayan akan terancam dan memunculkan kemiskinan baru. Untuk itu perlu suatu inovasi dalam pemberdayaan masyarakat nelayan agar mampu meningkatkan produktivitasnya. Pendekatan pemberdayaan dimaksudkan agar masyarakat dapat eksis pada usahanya dan terhindar dari kemiskinan dengan menggunakan potensi dan sumberdaya yang dimilikinya. Salah satu gagasan untuk proses pemberdayaan tersebut adalah mendifusikan inovasi peningkatan kapasitas kelembagaan yang ada agar nelayan mampu mengelola sumber daya lingkungan perairan.

Kelembagaan-kelembagaan yang ada di masyarakat menjadi salah satu komponen penting untuk peningkatan kesejahteraan masyarakat. Selain berfungsi sebagai agen sosialisasi perubahan terencana yang tumbuh dari masyarakat, kelembagaan dapat berperan sebagai perekat dan penguat keberhasilan serta keberlanjutan kegiatan-kegiatan yang ada di masyarakat. Dalam konteks pemberdayaan, suatu kegiatan dapat bertahan lama dan berkelanjutan apabila didukung oleh kelembagaan lokal yang berakar di masyarakat.

Menurut Uphoff (1986) yang menekankan pada kelembagaan berwujud organisasi ketimbang kelembagaan yang selama ini dijuluki sebagai tradisional. Dengan kelembagaan lokal yang dimaksud adalah semua kelembagaan yang memiliki struktur dan aturan yang berada pada level lokalitas (atau setingkat kota kecamatan di Indonesia) sampai level grup (seperti kelompok rumah tangga/ Rukun Tetangga di Indonesia). Menurutnya kelembagaan lokal meliputi kelembagaan di sektor publik (public sector), sektor sukarela (voluntary sector), dan sektor privat (privat sector). $\mathrm{Hal}$ penting lainnya teriait dengan program pembangunan pedesaan adalah memulai dengan pemetaan terhadap kelembagaan lokal yang ada untuk membangun tindakan bersama) (collective action) .Tindakan bersama menjadi pijakan penting dengan tujuan membagi keuntungan, menguatkan legitimasi dan harapan. Berdasarkan gambaran tersebut, maka penelitian ini bertujuan untuk mengkaji informasi tentang difusi peningkatan kapasitas kelembagaan pengelolaan surberdaya perikanan pada masyarakat nelayan di Waduk Malahayu, Kabupaten Brebes, Jawa Tengah.

\section{METODOLOGI}

Penelitian ini dilaksanakan pada bulan Juli 2012 dengan lokasi penelitian yaitu di Waduk Malahayu, Kabupaten Brebes, Jawa Tengah yang dipilih secara sengaja. Penelitian ini merupakan penelitian kualitatif dengan pendekatan studi kasus (case study). Data yang dikumpulkan adalah data primer dan data sekunder. Data primer adalah data yang langsung diperoleh dari pengamatan atau pengukuran langsung dari objek penelitian. Dalam penelitian ini, pengumpulan data primer dilakukan dengan cara wawancara langsung dengan para nelayan dengan bantuan daftar pertanyaan terstruktur. Data sekunder diperoleh dari studi literatur yang dengan kebutuhan penelitian ini. Teknik pengambilan sampel yang digunakan adalah purposive sampling pada nelayan yang melakukan aktivitas penangkapan ikan di Waduk Malahayu. Sebanyak 60 nelayan menjadi responden dengan kriteria pemilihan atau mengutamakan responden yang terbuka. Data yang diperoleh akan dianalisis deskriptif kualitatif.

\section{DIFUSI INOVASI DAN PENGADOPSIAN PENINGKATAN KAPASITAS KELEMBAGAAN}

Difusi didefinisikan sebagai suatu proses dimana suatu inovasi dikomunikasikan melalui saluran tertentu selama jangka waktu tertentu terhadap anggota suatu sistem sosial. Difusi dapat dikatakan juga sebagai suatu tipe komunikasi khusus dan pesannya adalah ide baru. Disamping itu, difusi juga dapat dianggap sebagai suatu jenis perubahan sosial yaitu suatu proses perubahan yang terjadi dalam struktur dan fungsi sistem sosial (Mulyana,2009).

Inovasi merupakan pangkal terjadinya perubahan sosial, yang merupakan inti dari pembangunan masyarakat. Masyarakat yang sedang membangun atau menata ulang kehidupannya, berkepentingan dengan inovasi, dengan penemuan-penemuan baru baik berupa gagasan, tindakan atau barang-barang baru. Proses menyebarkan inovasi membutuhkan waktu dan sasaran yang pelaksanaannya tidaklah mudah. Ide-ide pembaruan yang dihasilkan dapat tersebar, diterima oleh anggota masyarakat dan digunakan secara tepat sehingga berdampak pada perubahan sosial yang lebih baik. Perlu komunikasi untuk usaha memasyarakatkan ide-ide baru masuk dalam sistem sosial dan mempengaruhinya.

Hal tersebut sesuai dengan yang dikemukakan Rogers dan Soemaker (1987) bahwa inti perubahan sosial adalah komunikasi. Komunikasi merupakan mekanisme yang menyebabkan adanya hubungan antar manusia dalam masyarakat dengan menggunakan lambang-lambang yang mengandung makna dan dapat dilakukan dengan menembus ruang dan menyimpannya dalam dimensi waktu. Dalam perspektif sosiologi, 
komunikasi itu mengandung pengertian sebagai suatu proses mentransmit/memindahkan kenyataankenyataan, keyakinan-keyakinan, sikap-sikap, reaksireaksi emosional yang menyangkut kesadaran manusia. Pemindahan tersebut berlangsung antara manusia satu kepada yang lainnya.

Lingkungan komunikasi, setidak-tidaknya mempunyai tiga dimensi, yaitu dimensi fisik, dimensi sosial psikologis, dan dimensi temporal. Ketiga dimensi tersebut sering kali bekerja bersama-sama dan saling berinteraksi, dan mempunyai pengaruh terhadap berlangsungnya komunikasi. Proses komunikasi ada dua yaitu primer dan sekunder. Proses komunikasi secara primer adalah komunikasi yang dilakukan secara tatap muka, langsung antara seseorang kepada yang lain untuk menyampaikan pikiran maupun perasaannya dengan menggunakan simbol-simbol tertentu, misalnya bahasa, kial, isyarat, warna, bunyi, bahkan bisa juga bau. Proses komunikasi secara sekunder adalah komunikasi yang dilakukan dengan menggunakan alat atau sarana sebagai media kedua setelah bahasa (Sutaryo, 2005).

Pada penelitian ini, menggolongkan 18 variabel inovasi sebagai penentu peningkatan kapasitas kelembagaan yang akan didifusikan kepada masyarakat nelayan yaitu: 1) Keterbaruan inovasi; 2) Kesesuaian inovasi kelembagaan dengan kebutuhan masyarakat nelayan; 3) Prioritas pengembangan disesuaikan dengan penghasilan nelayan/miskin; 4) Penetapan lokasi berdasarkan lokasi penerapan program BalitbangKP; 5) Tingkat kepercayaan masyarakat nelayan pada inovasi; 6) Inovasi kelembagaan dapat memberikan nilai tambah pada kehidupan nelayan; 7) Respon masyarakat terhadap inovasi; 8) Kesesuian komoditas dengan aksesibilitas; 9) Kelompok sasaran merupakan kelompok yang sudah ada, masih eksis dan aktif; 10) Dapat dipercaya dan bisa bekerjasama; 11) Inovasi kelembagaan dapat memperbaiki sistem kelembagaan masyarakat yang dinilai kurang; 12) Inovasi dilakukan secara intensif dan periodik; 13) Pemberian bimbingan, pelatihan dan pendampingan dalam penerapan inovasi; 14) Tingkat pengetahuan dan pemahaman masyarakat terhadap inovasi; 15) Inovator; 16) Tingkat manfaat inovasi; 17) Keselarasan inovasi dengan program bebantuan di masyarakat; 18) Konsultasi tentang inovasi.

Dari penilaian keseluruhan variabel tersebut, diperoleh nilai 35 atau sebesar 97,22\% dari nilai maksimum yaitu 36. Peningkatan kapasitas kelembagaan yang diperkenalkan kepada masyarakat nelayan (anggota kelompok nelayan) sudah sesuai dengan kebutuhan masyarakat nelayan secara keseluruhan. Sebagai contohnya, teknologi pembenihan ikan patin beserta kelembagaannya yang diperkenalkan kepada masyarakat nelayan (anggota kelompok nelayan) sudah sesuai dengan kebutuhan masyarakat nelayan. Kemudian, pendekatan peningkatan kapasitas kelembagaan yang terkait dengan upaya konservasi sumberdaya perikanan yang diperkenalkan kepada masyarakat nelayan (anggota kelompok nelayan) sudah sesuai dengan kebutuhan masyarakat nelayan.

Penentuan prioritas pengembangan kawasan sudah dilakukan berdasarkan data dan infomasi yang sudah sesuai dengan kawasan yang memiliki potensi sumberdaya untuk dikembangkan, walaupun belum terkait dengan kebutuhan masyarakat terhadap inovasi kelembagaan. Sebenarnya, prioritas pengembangan kawasan telah disesuaikan dengan kondisi sebagian besar masyarakat/nelayan yang berpenghasilan rendah atau nelayan miskin. Penetapan lokasi (lokasi penerapan) sebagai tempat penerapan Model Inovasi Kelembagaan tersebut sudah ditentukan bersama oleh Badan Penelitian dan Pengembangan kelautan dan Perikanan (Balitbang KP) dan Pemerintah Daerah (Pemda setempat). Penetapan lokasi juga mempertimbangkan kepercayaan masyarakat terhadap inovasi yang dikenalkan bahwa inovasi kelembagaan mempunyai peranan yang sangat penting dalam pemanfaatan dan pengelolaan perairan umum waduk. Kemudian, inovasi kelembagaan yang diterapkan tersebut dapat memberikan nilai tambah atau pendapatan/hasil yang lebih tinggi dibandingkan dengan kondisi sebelumnya.

Proses difusi inovasi melibatkan empat unsur utama, meliputi 1) inovasi; 2) saluran komunikasi; 3) sistem sosial; dan 4) kurun waktu tertentu (Rogers dalam Bungin, 2007). Pertama, secara umum inovasi didefinisikan sebagai suatu ide/gagasan, praktek/ tindakan atau obyek yang dianggap sebagai sesuatu yang baru oleh seorang individu atau satu unit adopsi lain. Thompson dan Eveland, 1967 (dalam Chaeruman, 2008) mendefinisikan inovasi sama dengan teknologi, yaitu suatu desain yang digunakan untuk tindakan instrumental dalam rangka mengurangi ketidak teraturan suatu hubungan sebab akibat dalam mencapai suatu tujuan tertentu. Jadi, inovasi dapat dipandang sebagai suatu upaya untuk mencapai tujuan tertentu. Dalam hal ini, kebaruan inovasi diukur secara subjektif menurut pandangan individu yang menerimanya. Jika suatu ide dianggap baru oleh seseorang maka itu adalah inovasi untuk orang itu. Konsep 'baru' dalam ide yang inovatif tidak harus baru sama sekali.

Hasil penelitian membuktikan bahwa sebanyak $62,5 \%$ responden menyatakan bahwa inovasi model peningkatan kapasitas kelembagaan masyarakat di perairan waduk Malahayu ini belum pernah diperkenalkan oleh pihak lain. Hasil pengamatan juga menjelaskan bahwa belum ada anggota masyarakat nelayan lainnya (termasuk kelompok sasaran) yang menggunakan model peningkatan kapasitas kelembagaan masyarakat di wilayah waduk Malahayu. Walaupun konsep peningkatan kapasitas kelembagaan yang dikenalkan tergolong mudah jika dipraktekkan. Sebaliknya, 37,5\% responden menyatakan bahwa mereka tidak tahu mengenai inovasi tersebut. 
Kedua, komunikasi dan salurannya, komunikasi adalah proses dimana partisipan menciptakan dan berbagi informasi satu sama lain untuk mencapai suatu pemahaman bersama. Komunikasi dalam proses difusi adalah upaya mempertukarkan ide baru (inovasi) oleh seseorang atau unit tertentu yang telah mempunyai pengetahuan dan pengalaman dalam menggunakan inovasi tersebut (innovator) kepada seseorang atau unit lain yang belum memiliki pengetahuan dan pengalaman mengenai inovasi itu (potential adopter) melalui saluran komunikasi tertentu.

Hasil penelitian menjelaskan bahwa penentuan lokasi yang ditetapkan menjadi tempat penerapan model inovasi kelembagaan tersebut sejalan dengan kebijakan dan Program Pemerintah Daerah karena sudah mendapat respon positif dari masyarakat nelayan dan Pemerintah Daerah. Informasi dari sekretaris Kelompok Nila Jaya menjelaskan bahwa kegiatan ini bersamaan adanya bantuan peralatan yang dapat mendukung kegiatan pembenihan dalam kegiatan penerapan peningkatan kapasitas kelembagaan. Bantuan peralatan tersebut berupa alat pengolahan kerupuk ikan dari Balai Besar Penelitian dan Pengembangan Pengolahan Produk dan Bioteknologi Kelautan dan Perikanan (BBP4BKP) yang secara teknis dapat melancarkan proses pengadopsian inovasi. Dengan demikian, saluran komunikasi inovasi melibatkan Pemda sebagai upaya pertukaran informasi yang didukung bantuan peralatan. Komoditas yang dikembangkan juga merupakan komoditas potensial yang dikembangkan sesuai dengan komoditas unggulan nasional atau daerah yang memiliki aksesibilitas yang tinggi dari sisi transportasi, komunikasi, dan keamanan. Komoditas tersebut adalah ikan patin yang merupakan bagian dari inovasi yang disampaikan pada kelompok sasaran.

Kelompok sasaran adalah tujuan dari proses difusi inovasi agar mengadopsi inovasi yang dikenalkan. Dalam penelitian ini, kelompok sasaran adalah kelompok masyarakat (nelayan) yang mengusahakan kegiatan penangkapan di Waduk Malahayu. Kriterianya adalah eksisitas usaha dan masih aktif, dapat dipercaya serta mampu mengembangkan usaha melalui kerjasama kelompok. Hasil pengamatan menunjukkan bahwa anggota kelompok merupakan pelaku usaha yang berpotensi dan berminat menjadi penggerak dalam mendorong perkembangan usaha penangkapan. Sejauh ini peningkatan kapasitas masyarakat nelayan memang diperlukan dalam rangka memperbaiki sistem kelembagaan yang ada dan sekaligus untuk melakukan penguatan kelembagaan yang dinilai kurang efektif (lemah). Dengan demikian, hal tersebut selaras dengan tujuan dari pengenalan model kelembagaan yang ingin meningkatkan kapasitas kelembagaan masyarakat yang melibatkan sistem sosial masyarakat lokal.

Sistem sosial merupakan unsur ketiga dalam proses difusi inovasi. Menurut Chaeruman (2008), sistem sosial adalah satu set unit yang saling berhubungan yang tergabung dalam suatu upaya pemecahan masalah bersama untuk mencapai suatu tujuan. Anggota dari suatu sistem sosial dapat berupa individu, kelompok informal, organisasi dan atau sub sistem. Proses difusi dalam kaitannya dengan sistem sosial ini dipengaruhi oleh struktur sosial, norma sosial, peran pemimpin dan agen perubahan, tipe keputusan inovasi dan konsekuensi inovasi.

Keempat adalah waktu. Dimensi waktu pada proses difusi berpengaruh dalam hal: 1) proses pengambilan keputusan inovasi, yaitu tahapan proses sejak seseorang menerima informasi pertama sampai ia menerima atau menolak inovasi; 2) keinovativan individu atau unit adopsi lain, yaitu kategori relatif tipe adopter (relatif lebih awal atau lebih lambat dalam menerima inovasi); dan 3) rata-rata adopsi dalam suatu sistem, yaitu seberapa banyak jumlah anggota suatu sistem mengadopsi inovasi dalam periode waktu tertentu.

Kegiatan peningkatan kapasitas masyarakat nelayan yang dilakukan Balitbang KP secara intensif dan periodik dalam memberikan bimbingan, pelatihan dan atau pendampingan selama penerapan inovasi kelembagaan tersebut. Untuk itu, pernah dilakukan evaluasi dampak penerapan Model Inovasi Kelembagaan dalam rangka menilai tingkat keberhasilan dari implementasi Penerapan Model Inovasi Kelembagaan tersebut, khususnya terkait dengan produktivitas dan pendapatan nelayan secara informal. Seluruh responden menyatakan bahwa mereka mengetahui model inovasi peningkatan kapasitas kelembagaan masyarakat yang dikenalkan pada mereka karena materinya mudah dipahami. Petugas yang memperkenalkan pendekatan peningkatan kapasitas kelembagaan tersebut adalah Tim Balitbang KP.

Seluruh responden menyatakan keikutsertaannya dalam persiapan introduksi peningkatan kapasitas kelembagaan karena sebelumnya telah dilakukan kegiatan sosialisasi. Responden telah mengetahui keberadaan dan memahami kegiatan pelatihan peningkatan kapasitas kelembagaan. Sebanyak 92,86\% responden menyatakan bahwa mereka merupakan bagian dalam kegiatan penerapan peningkatan kapasitas kelembagaan dan dapat memahami sekaligus dapat menerapkan kegiatan tersebut. Namun masyarakat nelayan menyayangkan kegiatan tersebut tidak didukung oleh sarana konsultasi kegiatan. Hal tersebut terkait dengan tingkat respon masyarakat dan keberhasilan aplikasi kegiatan tersebut (adopsi). Dengan demikian dapat disimpulkan bahwa tahapan pengenalan inovasi peningkatan kapasitas kelembagaan pada masyarakat nelayan di Perairan Waduk Malahayu sesuai dengan pemikiran Everett M. Rogers (pencetus teori difusi inovasi). Roger (1995) dalam Bungin (2007) menjelaskan bahwa teori difusi inovasi memiliki relevansi dan argumen yang cukup signifikan dalam proses pengambilan keputusan inovasi (adopsi). Berikut 
tahapan dari dari proses pengenalan inovasi dan tingkat adopsinya serta pengambilan keputusan inovasi:

1. Mempelajari Inovasi: Tahapan ini merupakan tahap awal ketika masyarakat mulai melihat, dan mengamati inovasi baru dari berbagai sumber. Kemudahan pengadopsian tergantung dari komunikasi dan salurannya sehingga mereka bisa menangkap inovasi baru yang ada. Jika sebuah inovasi dianggap sulit dimengerti dan sulit diaplikasikan, maka hal itu tidak akan diadopsi dengan cepat oleh mereka, lain halnya jika yang dianggapnya baru merupakan hal mudah, maka mereka akan lebih cepat mengadopsinya. Beberapa jenis inovasi bahkan harus disosialisasikan melalui komunikasi interpersonal dan kedekatan secara fisik.

2. Pengadopsian: Dalam tahap ini masyarakat mulai menggunakan inovasi yang mereka pelajari. Diadopsi atau tidaknya sebuah inovasi oleh masyarakat ditentukan juga oleh beberapa faktor. Riset membuktikan bahwa semakin besar keuntungan yang didapat, semakin tinggi dorongan untuk mengadopsi perilaku tertentu. Adopsi inovasi juga dipengaruhi oleh keyakinan terhadap kemampuan seseorang. Sebelum seseorang memutuskan untuk mencoba hal baru, orang tersebut biasanya bertanya pada diri mereka sendiri apakah mereka mampu melakukannya. Jika seseorang merasa mereka bisa melakukannya, maka mereka akan cenderung mangadopsi inovasi tersebut. Adopsi inovasi juga dipengaruhi oleh nilai yang dimiliki individu tersebut serta persepsi dirinya. Jika sebuah inovasi dianggapnya menyimpang atau tidak sesuai dengan nilai yang ia anut, maka ia tidak akan mengadopsinya. Semakin besar pengorbanan yang dikeluarkan untuk mengadopsi sebuah inovasi, semakin kecil tingkat adopsinya.

3. Pengembangan Jaringan Sosial: Seseorang yang telah mengadopsi sebuah inovasi akan menyebarkan inovasi tersebut kepada jaringan sosial di sekitarnya, sehingga sebuah inovasi bisa secara luas diadopsi oleh masyarakat. Difusi sebuah inovasi tidak lepas dari proses penyampaian dari satu individu ke individu lain melalui hubungan sosial yang mereka miliki. Riset menunjukkan bahwa sebuah kelompok yang solid dan dekat satu sama lain mengadopsi inovasi melalui kelompoknya.

Teori difusi inovasi selalu dikaitkan dengan proses pembangunan masyarakat. Inovasi merupakan awal untuk terjadinya perubahan sosial yang merupakan inti dari pembangunan masyarakat. Teori difusi inovasi pada dasarnya menjelaskan proses bagaimana suatu inovasi disampaikan (dikomunikasikan) melalui saluransaluran tertentu sepanjang waktu kepada sekelompok anggota dari sistem sosial. Inovasi peningkatan kapasitas kelembagaan masyarakat yang dikenalkan pada masyarakat nelayan Waduk Malahayu merupakan ide baru untuk menciptakan perubahan sosial yaitu peningkatan kesejahteraan dengan mengotimalkan sumberdaya lokal yang dimiliki.

\section{KESIMPULAN}

Program pemberdayaan masyarakat nelayan yang paling efektif dapat dilakukan dengan memanfaatkan kelembagaan lokal masyarakat. Kelembagaan dapat berfungsi sebagai agen sosialisasi dan penguat keberhasilan adopsi inovasi yang dilakukan masyarakat. Inovasi yang didifusikan pada masyarakat adalah model peningkatan kapasitas kelembagaan masyarakat. Inovasi yang dikenalkan pada masyarakat nelayan Waduk Malahayu merupakan program Balitbang KP yang baru diterima masyarakat nelayan. Proses difusi inovasi melalui komunikasi dengan kelompok Nila Jaya yang dijadikan kelompok sasaran. Untuk percepatan pengadopsian dilakukan sosialisasi dan pendampingan dalam memahami inovasi yang dikenalkan secara intensif dan periodik. Secara informal, telah dilakukan evaluasi dampak penerapan inovasi peningkatan kapasitas kelembagaan, yang menunjukkan bahwa masyarakat nelayan telah meresponnya. Proses tersebut telah menimbulkan perubahan sosial melalui hasil tangkapan yang diharapkan dapat meningkatkan pendapatan nelayan.

\section{DAFTAR PUSTAKA}

Bungin. 2007. Sosiologi Komunikasi: Teori, Paradigma dan Diskursus Teknologi Komunikasi Di Masyarakat. Kencana Prenada Media Group. Jakarta.

Chaeruman. 2008. Adopsi Inovasi. www.damandiri.or.id. Diakses tanggal 22 Juni 2012.

Effendi. 2004. Pengantar Akuakultur. Penebar Swadaya. Jakarta.

Mulyana. 2009. Ilmu Komunikasi Suatu Pengantar. PT Remaja Rosdakarya. Bandung

Rogers, M. dan F. Shoemaker. 1987. Communication of Innovations. Terjemahan Abdillah Hanafi. Memasyarakatkan Ide-Ide Baru. Usaha Nasional. Surabaya.

Sutaryo. 2005. Sosiologi Komunikasi: Perspektif Teoritik. Arti Bumi Intaran. Yogyakarta.

Uphoff. 1986. Local Institutional Development: An Analytical Sourcebook With Cases. Kumarian Press.

Wahyudi, S.I. dan Santoso. 2002. Kaji Ulang Pedoman Operasioanal dan Pengukuran Ecahounding Waduk Malahayu. Laporan Akhir Dinas PSDA JawaTengah dan Linmit Unisula Semarang. 